\title{
EL EROTISMO Y RUBÉN DARÍO, UN RECORRIDO TEÓRICO
}

\author{
Sabrina Nair Roldán \\ (Universidad Nacional de La Plata) \\ sabrinaroldan3@gmail.com
}

RESUMEN: En el siguiente artículo hacemos un recorrido teórico por la categoría erotismo desde el texto clásico de Georges Bataille y otros textos conocidos, para analizar la poesía de Rubén Darío. El erotismo y lo femenino en la poesía de Darío refuerzan un universo metapoético donde la referencia no es una mujer en particular sino la poesía misma.

PALABRAS Clave: Rubén Darío, modernismo, Prosas profanas, erotismo.

\section{RUBÉN DARÍO AND EROTISM, A THEORETICAL JOURNEY}

ABSTRACT: In the following article we make a theoretical journey through the erotism category from the classic text of Georges Bataille and other known texts, to analyze the poetry of Rubén Darío. Eroticism and the feminine in Darío's poetry reinforce a metapoetic universe where the reference is not a particular woman but poetry itself.

KEYWORDS: Rubén Darío, Modernism, Prosas profanas, eroticism.

El estudio del erotismo en el poeta nicaragüense ha sido inicialmente analizado por un texto fundador, La poesía de Rubén Darío (1948) de Pedro Salinas, donde se considera la concepción erótica dariana en términos clásicos, es decir, que el amor representa una fuerza, un impulso vital que, si bien supone un objeto de deseo diversificado, privilegia el goce propio (Salinas, 1978: 61). Este erotismo que Salinas llama más elemental está presente en Azul... (1888) y en Prosas profanas (1896). A partir de este poemario y en consonancia con Cantos de vida y esperanza (1905) adquiere el estatus de religión (Salinas, 1978).

Otro texto muy citado es el de Ricardo Gullón, «Rubén Darío y el erotismo» (1967); este estudioso explica que el erotismo es una forma de trascendencia vinculada a la muerte; en este contexto Rubén Darío se destaca por privilegiar el deseo y el placer pues su erotismo es «de época» al estar en consonancia con la concepción erótica del «clima universal» (Gullón, 1967: 146). ${ }^{1}$

En cuanto a la teoría del erotismo, el libro homónimo de 1979 de Georges Bataille es, como se sabe, el texto clásico. El autor propone que no se puede estudiar el erotismo sin considerar la historia del trabajo y la historia de las religiones (1979). Para

${ }^{1}$ A esta misma idea se adhiere José Nelson Barría Navarro en su texto de 1996 «Erotismo satánico y muerte en la obra de Rubén Darío: una revisión de sus influencias» y Patiño Káram con su trabajo «El erotismo en los cuentos de $A z u l . .$. de Rubén Darío como propuesta vital» de 2005. 
ello construye la fórmula del erotismo: «la aprobación de la vida hasta en la muerte» (Bataille, 1979: 15), este será nuestro punto de partida en el presente artículo. ${ }^{2}$

\title{
EROTISMO, APROBACIÓN DE LA VIDA HASTA EN LA MUERTE
}

Georges Bataille, en su libro El erotismo (1979), piensa el sentido del erotismo con la fórmula «es la aprobación de la vida hasta en la muerte». Como una de las formas particulares de la actividad sexual reproductiva (Bataille, 2010: 15), este fin da vida y muerte a la vez y es común a los hombres y a los animales; se diferencia de estos últimos por una búsqueda psicológica independiente del fin natural del que hablamos, la reproducción. Aunque el erotismo sea una exuberancia de la vida, no es ajeno a la muerte; esta relación es la que el autor se ocupa de desentrañar. Tomamos una cita sobre estos primeros lineamientos del escritor francés:

\begin{abstract}
Intentaré mostrar ahora que para nosotros, que somos seres discontinuos, la muerte tiene el sentido de la continuidad del ser. La reproducción encamina hacia la discontinuidad de los seres, pero pone en juego su continuidad; lo que quiere decir que está íntimamente ligada a la muerte. Precisamente, cuando hable de la reproducción de los seres y de la muerte, me esforzaré en mostrar lo idénticas que son la continuidad de los seres y la muerte. Una y otra son igualmente fascinantes, y su fascinación domina al erotismo (Bataille, 2010: 17).
\end{abstract}

Aunque concibe tres tipos de erotismo: el de los cuerpos, el de los corazones y, por último, el sagrado, para Bataille todo erotismo está inmerso en esta última clasificación. La operación erótica tiene como finalidad alcanzar al ser en lo más íntimo, «hasta el punto del desfallecimiento». El paso del ser a un estado de deseo erótico «supone una disolución relativa del ser, tal como está constituido en el orden de la discontinuidad. Este término de disolución responde a la expresión corriente de la vida disoluta, que se vincula con la actividad erótica». La destrucción de toda operación erótica (Bataille, 2010: 20-22) es lo que veremos en la poesía de Darío: el ser es destruido en la experiencia poética del erotismo, es disuelto en las diferentes personificaciones de su naturaleza erótica.

Otra cuestión es el tema del sacrificio; sobre ello Bataille dice: «En la antigüedad, la destitución o la destrucción que está en los fundamentos del erotismo era lo bastante sensible para justificar una semejanza entre el acto de amor y el acto de sacrificio» (Bataille, 2010: 23). La destrucción del ser, entonces, se encuentra tanto en el sacrificio como en el erotismo: este desborda los límites del ser y, por lo tanto, es difícil de explicar con palabras.

Según el filósofo, lo erótico surge en el hombre de una actividad que es el acto sexual con fines reproductivos que dan vida pero que a su vez activan la venidera muerte, esto se traspasa al entrar en juego el placer y el goce que tantas controversias presenta en muchas religiones y que dan vía a las prohibiciones y transgresiones:

${ }^{2}$ El presente artículo integra la tesina de grado aprobada «Erotismo e imágenes femeninas en Prosas profanas de Rubén Darío. Una reinvención dariana», del año 2018. 
Esta doble experiencia no se suele dar. Las imágenes eróticas, o religiosas, introducen esencialmente, en unos, los comportamientos de la prohibición, en otros, unos comportamientos contrarios. Los primeros son tradicionales. Los segundos son comunes en sí mismos, al menos bajo la forma de un pretendido retorno a la naturaleza, a la cual se oponía la prohibición. Pero la transgresión difiere del «retorno a la naturaleza»: levanta la prohibición sin suprimirla. Ahí se esconde el impulso motor del erotismo; ahí se encuentra a la vez el impulso motor de las religiones (Bataille, 2010: 40; cursiva del autor).

La fórmula que el teórico repite en su libro es el erotismo como la aprobación de la vida hasta en la muerte y la explica de la siguiente manera:

La aprobación de la vida hasta en la muerte es un desafío, tanto en el erotismo de los corazones como en el erotismo de los cuerpos. Es un desafío a través de la indiferencia, a la muerte. La vida es acceso al ser; y, si bien la vida es mortal, la continuidad del ser no lo es. Acercarse a la continuidad, embriagarse con la continuidad, es algo que domina la consideración de la muerte. En primer lugar, la perturbación erótica inmediata nos da un sentimiento que lo supera todo; es un sentimiento tal que las sombrías perspectivas vinculadas a la situación del ser discontinuo caen en el olvido (Bataille, 2010: 29).

Nacemos como seres discontinuos y es en el evento erótico donde encontramos una profunda continuidad del ser, que a su vez es hallar la vida y la muerte. La vida es la continuidad del ser y es lo que el erotismo intenta reproducir. Esta continuidad está plenamente unida a la muerte que no es la negación de la vida sino, más bien, su afirmación y confirmación. La muerte sella la continuidad del ser y anula su discontinuidad.

\section{¿HABLAMOS DE LA MISMA COSA CUANDO HABLAMOS DE AMOR?}

Julia Kristeva comienza su libro Historias de amor con una pregunta «¿Hablamos de la misma cosa cuando hablamos de amor?, ¿y de qué cosa?» (Kristeva, 1987: 2). Cuando hablamos del amor en Rubén Darío sucede algo parecido: ¿de qué hablamos cuando hablamos de erotismo en su poesía?, ¿hay un solo erotismo? ${ }^{3}$ Kristeva continúa exponiendo que en el amor el yo ha sido otro: «Esta fórmula que nos conduce a la poesía o a la alucinación delirante sugiere un estado de inestabilidad en el que el individuo deja de ser indivisible y acepta perderse en el otro, para el otro» (Kristeva, 1987: 4). Plantea, al igual que Bataille, que el amor lleva a la continuidad de los seres, a la unión del yo con el otro. Paz se refiere a lo mismo al hablar de la unidad en el amor. Él propone que la tradición de la poesía hispanoamericana amorosa, provenzal o platónica, tiene al individuo como una realidad refleja: el fin del amor es la contemplación y no la pasión carnal. Esto es la pasión de la unidad, la previa a la unión

${ }^{3}$ En Rubén Darío y en Julia Kristeva no se encuentra una distinción entre amor y erotismo, por lo tanto no es una distinción que tomamos, tampoco, en este artículo. 
del alma humana y el espíritu (Paz, 2007: 44). Para relacionar estas ideas con las aspiraciones de Rubén Darío al hablar del amor, citamos a Paz quien considera que Darío propone lo contrario ya que:

Quiere disolverse en cuerpo y alma en el cuerpo y el alma del mundo. La historia de su corazón es plural en dos sentidos: por el número de mujeres amadas y por la fascinación que experimenta ante la pluralidad cósmica. Para el poeta platónico la aprehensión de la realidad es un paulatino tránsito de lo vario a lo uno; el amor consiste en la progresiva desaparición de la aparente heterogeneidad del universo. Darío siente esa heterogeneidad como la prueba o manifestación de la unidad: cada forma es un mundo completo y simultáneamente es parte de la totalidad. La unidad no es una; es un universo de universos, movido por la gravitación erótica: el instinto, la pasión. El erotismo de Darío es una visión mágica del mundo (Paz, 2007: 44). ${ }^{4}$

Un poema de Darío que ilustra estas ideas de Kristeva cruzadas con la de Paz es «Que el amor no admite cuerdas reflexiones». ${ }^{5}$ El sujeto lírico le canta a la «señora», apelativo que se toma de la lírica de amor cortés; ${ }^{6}$ la «señora», por lo tanto, no tiene nombre propio, es una y todas, y le explica que el Amor (con mayúsculas porque es Eros), es violento y nos devora, nos modifica las ideas y el pensamiento. El nosotros inclusivo se refiere tanto al sujeto poético como a los seres humanos que son tocados por el Amor, la heterogeneidad que forma la totalidad. Este es un poema escrito a la multiplicidad, a todas las mujeres que en algún momento fueron causa del amor; el sentimiento que en todos despierta este amor es la unidad del poema. A su vez también lo es el desborde, la violencia que genera el amor y el erotismo, que no son diferenciados.

${ }^{4}$ Sucre en el comienzo del capítulo «El universo el verso de su música activa», escribe que: «Darío ve el universo como una realidad mágica: una simpatía universal relaciona a los seres y las cosas. [...] Así, el universo es para Darío campo de continuas mutaciones [...] está, igualmente, regido por un orden superior y fatal [...] Sin dejar de ser realidad —o por serlo—, es también símbolo: lo visible revela lo invisible, la materia se torna espíritu. El universo es, pues, sagrado. Un cosmos» (Sucre, 1975: 35).

${ }^{5}$ Todas las citas de los poemas son tomadas de la edición Prosas profanas y otros poemas (1996 [1896]). Este poema en particular pertenece al apartado «Dezires, layes y canciones», el subtítulo «(A la manera de Santa Fe)» indica la fuente utilizada por Darío, que es la mística española como, también, expresa en «Palabras liminares»: «Yo le pregunto por el noble Gracián, por Teresa la Santa, por el bravo Góngora y el más fuerte de todos, don Francisco de Quevedo y Villegas» (Darío, 1996: 75).

${ }^{6}$ Son los poetas italianos del dolce stil novo quienes recrean la tradición idealizante del amor cortés. Se hace una correlación directa entre el señor y sus vasallos. El llamado corazón gentil se refugia en el Amor, donde la gentileza es indispensable para que el amor se manifieste; tiene, como se sabe, influencia de la filosofía platónica. Entre sus tópicos se puede encontrar el del enaltecimiento, la sumisión, la guerra (Paz, 1991 [1982]; Lafitte-Houssat, 1996). Encontramos, además, intertextos de la invocación «señora» y el tópico de la guerra en la poesía de Verlaine, que sabemos forma parte del panteón de escritores de Darío; damos un ejemplo del poema «Lettre»: «Éloigné de vos yeux, Madame, par des soins/Impérieux (j'en prends tous les dieux à témoins) [...] N'en doutez pas, Madame, et je saurai combattre/Comme César pour un sourire, ô Cléopâtre/Et comme Antoine fuir au seul prix d'un baiser» (Verlaine, 2011: 135-136): la cita del poema de Darío es, por cierto, un ejemplo en el cual se ponen en diálogo ambas tradiciones. 
Señora, Amor es violento, y cuando nos transfigura nos enciende el pensamiento la locura.

No pidas paz a mis brazos que a los tuyos tienen presos: son de guerra mis brazos y son de incendio mis besos; y sería vano intento el tornar mi mente oscura si me enciende el pensamiento la locura (Darío, 1996: 196).

Los tópicos provenientes de la guerra también son propios del amor cortés. El sujeto poético se enfrenta a la sumisión de la señora que tiene sus brazos apresados. La dinámica es la de batallar por el amor hasta conquistarlo, es la dinámica del amo y el vasallo. Sobre este verso que hemos analizado («son de guerra mis brazos»), Rama explica: «La relación erótica se plantea como una batalla sin tregua que convoca a la mujer a la misma pugna, develando una naturaleza paralela para el placer» (Rama, 1985: XL).
Clara está la mente mía de llamas de amor, señora, como la tienda del día o el palacio de la aurora.
$\mathrm{Y}$ al perfume de tu ungüento te persigue mi ventura, $\mathrm{y}$ enciende el pensamiento la locura.

Mi gozo tu paladar rico panal conceptúa, como en el santo Cantar: Mel et lac sub lingua tua. La delicia de tu aliento en tan fino vaso apura, y me enciende el pensamiento la locura (Darío, 1996: 197).

Darío realiza una resemantización de la filosofía del amor cortés: en lugar de un cuerpo idealizado hay una corporalidad concreta: el paladar, la lengua y el aliento que el sujeto poético goza. No hay una sublimación de la sexualidad como en la tradición idealizante del amor cortés donde, a veces, solo existía una contemplación de cuerpos desnudos como punto máximo de intimidad. 
La operación que Darío aplica partiendo de los conceptos cuerpo, mente y espíritu tiene como intertexto el Cantar de los Cantares, ${ }^{7}$ «Mel et lac sub lingua tua». El libro se encuentra en el Antiguo Testamento y Julia Kristeva lo analiza en Historias de amor. Según la autora esta obra contiene una dinámica compleja del amor bíblico: el hecho de que el amor en el libro sea presentado como el antídoto de la muerte ha llevado a estudiosos a analizar la relación entre este y las celebraciones orgiásticas de los cultos funerarios babilónicos y griegos. También piensan esta relación a raíz de la cita que vincula amor y muerte («es tan fuerte el amor como la muerte») (Kristeva, 1987: 74-75). ${ }^{8}$ El versículo refiere una idea sencilla: la imposibilidad de evadirse de la muerte; el amor tiene la misma radicalidad pues no se puede soslayar, es una condición indeclinable para el que lo padece. Este es uno de los pasajes más importantes del Cantar pues define el amor: «En ninguna parte del Cantar se había dado la definición del amor. La novia la da aquí en los más fuertes y bellos términos, expresando su poder invencible, su carácter ineluctable, su valor sin igual». ${ }^{9}$ Seguramente Darío leyó la Vulgata $^{10}$ y por eso cita en latín recuperando, por cierto, la autoridad y condición sagrada de esta lengua. En el Cantar de los Cantares la relación entre amor y muerte está dada por la implacabilidad de ambos.

Se puede hacer una analogía entre el análisis de Kristeva del Cantar de los Cantares y el análisis del poema citado. Uno de los recursos estudiados del libro bíblico es la repetición «al nivel de las pequeñas unidades del discurso de las comparaciones o metáforas codificadas, y su disminución al nivel superior de la organización lógica del conjunto sugieren el impacto de la pulsión de muerte en la invocación amorosa» ${ }^{11}$ (Kristeva, 1987: 79). Darío repite el tópico del fuego amoroso, con algunas variaciones, al final de cada estrofa: «nos enciende el pensamiento / la locura», «si me enciende el pensamiento / la locura», «y me enciende el pensamiento / la locura». El erotismo de Darío es hedonista y, por lo tanto, no hay pulsión de muerte, pero esta locura no está alejada de esa muerte simbólica que el erotismo y el amor conlleva. En este poema el amor y el erotismo se unen en la violencia que la pasión provoca en el pensamiento. Darío elige un texto bíblico, probablemente, para expresar la sacralidad de su erotismo; integra al ser humano privilegiando la corporalidad y retomando de la lírica mística lo sagrado, así une al ser humano y al otro, el objeto del deseo. Podemos concluir la idea con una cita de Bataille: «La determinación del erotismo es primitivamente religiosa» (Bataille, 2010: 36).

\footnotetext{
${ }^{7}$ Sobre la fecha del Cantar de los Cantares Kristeva dice: «Para algunos, el texto, que hace numerosas referencias a Salomón, habría sido compuesto por el propio Salomón, hijo de David. La fecha más antigua ha sido fijada hacia el 915-913 antes de nuestra era. Esta opinión prevalece entre los críticos judíos y cristianos del siglo XIX. Otros consideran que el texto es más reciente, pero que contiene alusiones a épocas arcaicas. Los autores que se basan en análisis lingüísticos estiman generalmente que el texto solo puede fecharse alrededor del siglo III antes de Cristo» (Kristeva, 1987: 72-73).

${ }^{8}$ La cita del Cantar de los Cantares es de la Biblia de Jerusalén (1998) revisada y aumentada, Bilbao, Desclée de Brouwer. Capítulo 8, versículo 6b.

${ }^{9}$ Nota de la Biblia de Jerusalén al versículo correspondiente (1998: 831).

${ }^{10}$ Primera traducción que llegó de los textos originales.

${ }^{11}$ El verso completo que analiza Julia Kristeva del Cantar de los cantares es: «Que es fuerte el amor como la muerte / y son como el sepulcro duros los celos. / Son sus dardos saetas encendidas, / son llamas de Yavé» (en Kristeva, 1987: 79).
} 
Tal como advertimos anteriormente, en el erotismo dariano el otro, (la mujer o las mujeres), es un ideal que está representado por diferentes arquetipos femeninos propios del arte de fines del siglo XIX. Kristeva escribe sobre la dinámica del ideal y es iluminador para pensar el complejo erotismo de Rubén Darío y su construcción de la subjetividad:

El sujeto solo existe si se identifica con otro ideal que es el otro que habla, el otro en cuanto hablante. Fantasma, formación simbólica más allá del espejo, ese Otro que tiene de hecho la grandiosidad de un Amo, es un polo de identificación porque no es un objeto de necesidad ni de deseo. Ideal del yo que incluye el Yo por el amor que ese Yo le manifiesta, lo unifica, frena sus pulsiones, y hace de él un Sujeto. Yo, cuerpo que hay que hacer morir, al menos diferir, por el amor del Otro y para que Yo sea. El amor es una muerte que me hace ser. Cuando la muerte intrínseca de la pasión amorosa se produce en la realidad y se lleva el cuerpo de uno de los enamorados, es la intolerable suprema; el enamorado superviviente mide entonces el abismo que separa la muerte imaginaria que vivía en su pasión de la implacable realidad de la que el amor le había siempre apartado, salvado (Kristeva, 1987: 30-31).

Es necesario pensar el vínculo que tienen, en la poética dariana, lo femenino y la poesía, ya que el discurso poético es un lenguaje propicio para expresar el impulso erótico. Darío le da a la palabra poética un estatus de ideal; además, para él, la poesía es la portadora de lo sensual; ello se aprecia en la mención a Silvano presente en las «Palabras liminares», uno de los símbolos de la pulsión sexual y muchas veces identificado con Pan y con la fertilidad:

Como cada palabra tiene un alma, hay en cada verso, además de la armonía verbal, una melodía ideal. La música es solo de la idea, muchas veces.

La gritería de trescientas ocas no te impedirá, Silvano, tocar tu encantadora flauta, con tal de que tu amigo el ruiseñor esté contento de tu melodía. Cuando él no esté para escucharte, cierra los ojos y toca para los habitantes de tu reino interior. ¡Oh pueblo de desnudas ninfas, de rosadas reinas, de amorosas diosas! (Darío, 1996: 76).

Veamos en el siguiente poema, «El poeta pregunta por Stella», cómo al construir al Otro, con típicos elementos eróticos modernistas crea, a su vez, un Yo que, como dice Kristeva, lo unifica y frena sus pulsiones. El resultado son versos tristes por la ausencia del otro. Por esta razón la flor elegida es el lirio que, como explica Litvak, es la flor que poco dice de los sentidos, pero mucho habla del alma pues está ligada a la castidad y la pureza, es blanca y refiere a la luna (Litvak, 1979: 43), es decir, inaccesible. Darío llama a este lirio, en consonancia con Litvak, «hermano perfumado de las estrellas castas»:

Lirio divino, lirio de las anunciaciones;

lirio, florido príncipe,

hermano perfumado de las estrellas castas,

joya de los abriles. 
A ti las blancas dianas de los parques ducales, los cuellos de los cisnes, las místicas estrofas de cánticos celestes, y en el sagrado empíreo la mano de las vírgenes.

Lirio, boca de nieve donde sus dulces labios la primavera imprime, en tus venas no corre la sangre de las rosas pecadoras, sino el ícor excelso de las flores insignes (Darío, 1996: 141-142).

La rosa roja es la flor que expresa la carnalidad en contraposición a las flores blancas, ${ }^{12}$ así lo explica Litvak en su análisis de la simbología de las flores en el fin del siglo XIX (Litvak, 1979: 45). Es el paralelo de la dicotomía Eva/María o femme fatale/mujer angelical. En este poema se puede apreciar esta idea en el verso «en tus venas no corre la sangre de las rosas / pecadoras». Quizás la elección de una flor que tiene relación con los jardines espirituales o místicos, con su reino interior, ${ }^{13}$ se funda en la ausencia de Stella (enlazada a las amadas etéreas de Poe) ${ }^{14}$ ya que el poeta pregunta por ella.

\author{
Lirio real y lírico \\ que naces con la albura de las hostias sublimes, \\ de las cándidas perlas \\ y del lino sin mácula de las sobrepellices: \\ ¿has visto acaso el vuelo del alma de mi Stella, \\ la hermana de Ligeia, por quien mi canto a veces es \\ tan triste? (Darío, 1996: 141-142).
}

\footnotetext{
${ }^{12}$ Giordano en su escrito nombra la rosa del poema «En el país de las alegorías» de Cantos de vida y esperanza: «El sentido terriblemente enigmático de la "rosa sexual"» (Giordano, 1979: 147).

${ }^{13}$ Explica Bataille que la experiencia interior del erotismo requiere del que la realiza una sensibilidad que no es menor a la angustia que funda lo prohibido, menor que al deseo que hace infringir la prohibición; continúa sobre esta idea diciendo: «Esta es la sensibilidad religiosa, que vincula siempre estrechamente el deseo con el pavor, el placer con la angustia» (Bataille, 2010: 43).

${ }^{14}$ Sobre la utilización del nombre Stella, Barcia anota: «Era el seudónimo con que firmaba sus poemas la primera esposa de Darío, Rafaela Contreras (1869-1893). El poeta le destinó una página evocativa "Stella" [...] que más tarde reelaborará en el ensayo sobre Poe en Los Raros, con leves retoques, allí dice: "¿Por qué viene tu imagen a mi memoria, alma, dulce reina mía, tan presto ida para siempre, hoy que después de recorrer el hirviente Broadway, me he puesto a leer las páginas de los versos de Poe - cuyo nombre Edgardo, armonioso y legendario, encierra tan vaga y triste poesía — [...]? Es porque tú eres hermana de las liliales vírgenes, cantadas en brumosa lengua inglesa por el soñador infeliz, príncipe de los poetas malditos [...] Tu nombre luminoso y simbólico, surge en el cielo de mis noches, como una incomparable guía"» (Darío, 1996: 141). Podemos pensar que lo femenino se enmarca en la técnica propia de $A z u l . .$. y de Prosas profanas a través de la cual Darío ensaya las estéticas de moda, en este caso al modo de Edgar Allan Poe.
} 
Consideramos necesario introducir en este trabajo una visión sobre el erotismo perteneciente a un escritor latinoamericano; para eso nos servimos de La llama doble (1993) de Octavio Paz que citáramos en las páginas precedentes. El autor parte de la explicación del título de su libro de la siguiente manera: «El fuego original y primordial, la sexualidad, levanta la llama roja del erotismo y esta, a su vez, sostiene y alza otra llama, azul y trémula: la del amor. Erotismo y amor: la llama doble de la vida». Así como el erotismo y el amor son la llama doble de la vida, el poeta considera que sentir y pensar se funde en la poesía (Paz, 1993: 11-12). Por lo tanto, el erotismo sería una metáfora de la sexualidad y la poesía una erotización del lenguaje (Paz, 1993: 50). En su concepción teórica considera que el erotismo es exclusivamente humano, no así la sexualidad que nos iguala a los animales, esta consideración es idéntica a la del francés Georges Bataille, como ya vimos.

Octavio Paz presenta una primera definición de erotismo: «es sexualidad socializada y transfigurada por la imaginación y la voluntad de los hombres» (Paz, 1993: 32). Continúa con consideraciones que serán claves para apreciar la concepción erótica de Rubén Darío, ya que el erotismo es dador de vida y de muerte (Paz, 1993: 40): «[...] es ante todo y sobre todo sed de otredad. Y lo sobrenatural es la radical y suprema otredad» (Paz, 1993: 50).

Los teóricos coinciden en relacionar la sexualidad y la reproducción al hablar del tema; Paz, con algunas metáforas, también hace lo propio haciendo alusión a conceptos inherentes al erotismo, como el ritmo, que separa y reconcilia al sujeto con la naturaleza:

Sí, el erotismo se desprende de la sexualidad, la transforma y la desvía de su fin, la reproducción; pero ese desprendimiento es también un regreso: la pareja vuelve al mar sexual y se mece en su oleaje infinito y apacible. Allí recobra la inocencia de las bestias. El erotismo es un ritmo: uno de sus acordes es separación, el otro es regreso, vuelta a la naturaleza reconciliada (Paz, 1993: 78).

Entre las declaraciones de Octavio Paz encontramos que el erotismo es inseparable de la muerte o la muerte del placer, así como Thánatos es la sombra de Eros: «La sexualidad es la respuesta a la muerte: las células se unen para formar otra célula y así perpetuarse. Desviado de la reproducción, el erotismo crea un dominio aparte regido por una deidad doble: el placer que es muerte» (Paz, 1993: 162). ${ }^{15}$

En su artículo «El caracol y la sirena», Paz considera que el placer es el tema central de Prosas profanas y continúa: «Solo que el placer, precisamente por ser un juego, es un rito del que no están excluido el sacrificio y la pena. [...] La religión de placer es una religión rigurosa» (Paz, 2007: 32-33). Quizá Paz haya leído a Bataille, ya que la conclusión de su libro Breve historia del erotismo es parecida:

15 Anderson Imbert escribe sobre el mundo enigmático de Rubén Darío donde no hay diferencia entre el bien y el mal: «Del fondo de ese Enigma recibimos la poderosa invitación al Sexo, que es vida y muerte» (Anderson Imbert, 1967: 92). 
La religión en su conjunto se funda en el sacrificio. Pero solo un rodeo interminable ha permitido acceder al instante en que visiblemente, los contrarios parecen ligados, donde el horror religioso que se da, lo sabemos, en el sacrificio, se liga con el abismo del erotismo, a los últimos sollozos que solo el erotismo ilumina (Bataille, 1981: 102).

\section{EROTISMO ELEMENTAL: ¿NO HAS DE SER ENTONCES MÍA HASTA LA MUERTE?}

Retomando a Salinas, la concepción erótica de Rubén Darío es clásica pues se considera al amor como una fuerza, un impulso vital de belleza propia, el que lo posee va de mujer en mujer, no hay una sola que prime sobre las otras porque lo que importa es el goce propio (Salinas, 1978: 61). Este erotismo que podemos llamar más elemental es el que destaca en la primera concepción dariana del tema amoroso, pero luego ello irá más allá y se tornará más profundo adquiriendo el estatus de religión. ${ }^{16}$ En palabras de Salinas: «Rubén, a quien ya no le basta para vivir su erotismo con la simple fuerza de sus sentidos, busca la potenciación, el esfuerzo de su sensualidad elemental, en esas fuerzas que se ocultan tras las figuras míticas» (Salinas, 1978: 86).

Acerca de una primera etapa del erotismo dariano, Salinas explica: «Es todo lo que al amor ${ }^{17}$ le llega por camino de los sentidos, y busca su satisfacción por la misma vía sensual. Los sentidos son los señores absolutos de la lírica de amor de Rubén, durante su primera época». Para él los poetas que escriben inspirados por la temática erótica tienen un lugar secundario, ${ }^{18}$ se justifica diciendo que la poesía de Rubén Darío se presenta bajo esta temática solo en una primera visión. Justamente, partiendo de esta consideración e intentando reivindicar al poeta nicaragüense, Salinas cree que el poeta se alza ante el «erotismo natural a una especie de conciencia de lo erótico» (Salinas, 1978: 58-59). ${ }^{19}$ El erotismo elemental de Darío, el que más arriba nombramos como clásico, no tiene a una mujer particular como objeto de deseo, sino que es direccionado por el placer amoroso, por el gozo simplemente. ${ }^{20}$

\footnotetext{
${ }^{16} \mathrm{Paz}$ al referirse al tema amoroso en poesía advierte que: «La mezcla entre erotismo y religión es universal y pertenece a todas las épocas. Los místicos cristianos y los musulmanes, creyentes en un solo Dios, usan las expresiones propias de la pasión amorosa con el mismo ardor, aunque con menos crudeza, que los de la India, sean estos politeístas o adoradores de la Vacuidad» (Paz, 1991: 268-269).

${ }^{17}$ En cuanto al uso del concepto de amor o erotismo, Salinas aclara: «Conviene a poesías de esta clase, más que el nombre de amorosas, rico en demasía, otro que fue por mucho tiempo y aún sigue usándose así, sinónimo suyo: erótico. Sin perder su capacidad de sinonimia con amor, en algunos casos intensifica el significado de deseo físico y su cumplimiento en el amor carnal» (Salinas, 1978: 59).

${ }^{18}$ Es preciso dejar constancia de todos los dichos de Salinas sobre los poetas eróticos: «Llamar erótico a un poeta con designio clasificativo y valoratorio, es colocarle encima una conceptuación diminutiva, privarlo de gran parte de su humanidad; "poetas eróticos" ya suenan a grupo semi-secreto de aficionados a un cierto tipo de arte, a una escuela de poesía menor que renuncia a afrontar los mayores significados de lo humano. Poetas, cuando más, si así se lo ganan su encanto, su gracia, de media estatura, no es posible colocar a Darío, que fue poeta en grande, entre ellos» (Salinas, 1978: 59).

${ }^{19}$ Veamos la lectura del libro de Pedro Salinas en palabras de Julio Ortega: «Pedro Salinas en su libro fundamental habló primero de un Eros de trascendencia, queriendo decir que lo erótico en Darío va más allá del placer. Y, sin embargo, bien visto, siempre el Eros es de trascendencia porque ningún deseo pierde el nombre en la consumación. Es decir, el deseo es siempre otro deseo» (Ortega, 2003: 25).

${ }^{20}$ Salinas se refiere a la falta de amada particular de la siguiente manera: «Este erotismo puro y sin mezcla, despojado de toda alianza espiritual, no puede dispararse hacia una amada única, ejemplar, en la cual se satisfaga por completo. Pone su mira en el género, en la mujer genérica, en lo femenino
} 
Salinas analiza el sonetillo hexasílabo «Mía» como una sublimación de la posesión, el pronombre posesivo se convierte en el nombre propio de la amada. La posesión se concreta al punto de desintegrar a la mujer llamada Mía.

\author{
Mía: así te llamas. \\ ¿Qué más armonía? \\ Mía: luz del día; \\ mía: rosas, llamas. \\ ¡Qué aromas derramas \\ en el alma mía, \\ si sé que me amas!, \\ ¡oh Mía!, ¡oh Mía! \\ Tu sexo fundiste \\ con mi sexo fuerte, \\ fundiendo dos bronces (Darío, 1996: 119).
}

El primer terceto contiene la unión sexual con la repetición de la palabra sexo y elementos propios de la estética parnasiana: el bronce duro y perdurable. Salinas sobre esta posesión dice: «Apurando, concentrando más y más ese foco final de su deseo, ni siquiera es la carne, sino en cuanto poseída; la cima de esa progresión llameante de su erotismo es la posesión. No era Eva. Es Mía. Ahí llega Rubén impelido por lo inexorable, lo cruel del destino de lo erótico, por lo que llamaríamos la fatalidad erótica» (Salinas, 1978: 68).

Rama, en su célebre prólogo a la poesía de Rubén Darío, dice que este es el poeta de la sensualidad, el artífice de cuadros que erizan la piel y de su música ostensible, pero cree que es ante todo el poeta de la violencia sexual, por su enorme capacidad para el remate del orgasmo (Rama, 1985: XLIV).

Yo triste, tú triste...

¿No has de ser entonces

mía hasta la muerte? (Darío, 1996: 119).

Luego de la consumación del acto sexual no queda otra cosa que la angustia, la pequeña muerte, la muerte simbólica de los seres discontinuos. Sobre el final se apela a la muerte real, que expresa la eternidad de la unión del poeta y de Mía. La pregunta retórica final subraya la fragmentariedad o la alienación de un amor que no es para siempre; propio de las fiestas galantes y sus amoríos pasajeros.

Ricardo Gullón en su texto «Rubén Darío y el erotismo» (1967) refuerza nuestra hipótesis al explicar que el erotismo parece ser una forma de trascendencia en el éxtasis del sentimiento y de los sentidos, que lleva post orgasmo a la extinción, a una «muerte

elemental, fémina o hembra. En la mujer, mejor aún en lo mujer, que está repartido en todas ellas y entero en ninguna. De ahí el amor plural, que Rubén confiesa» (Salinas, 1978: 63). 
chica que prefigura la pérdida de conciencia en que el morir consiste» (Gullón, 1967: 143). La sexualidad, para él, funciona independientemente del amor y con otras leyes, el deseo es insaciable y puede completarse totalmente «en el extravío o en la muerte». En cuanto al erotismo dariano, plantea que es personal y de época o sea en consonancia con la concepción erótica del «clima universal». Este erotismo finisecular tiene dos direcciones: «hacia la idealización de la mujer y hacia lo morboso de la cosificación de quien se deja gozar, instrumentalizando al gozador» (Gullón, 1967: 145-147).

Gullón advierte que Rubén Darío hizo referencia a «la palpitación sexual»: «cuyo latido le perturbaba, y es visible que en su poesía ese latido tiene algo de religioso, no en la acepción corriente del término», ya que los excesos de pasión son comunes en el erotismo y en la religión. Uno de los ejemplos que el crítico toma es «Ite, missa est»: «más les sonará a blasfemia que a plegaria, aunque como oración se admita en el contexto imaginado por Valera». La aclaración sobre los dichos de Valera es porque este consideraba que Eros podía ser objeto de agradable culto (Gullón, 1967: 149-150).

Si leemos el soneto alejandrino «Ite, missa est» a partir de nuestra clave de lectura vemos cómo el sujeto poético desde un «Yo» presente en los primeros versos establece su adoración por una mujer que es una femme angelical y que será la envidia de la femme fatale representada por la mujer enigma en la esfinge y la faunesa:

Yo adoro a una sonámbula con alma de Eloísa, virgen como la nieve y honda como la mar; su espíritu es la hostia de mi amorosa misa y alzo al son de una dulce lira crepuscular (Darío, 1996: 123).

La descripción de la mujer virgen y angelical se presenta desde un campo semántico propio de la temática religiosa y el poema se convierte en una misa. La verdadera misa es la adoración de esta femme angelical. Es lo sagrado lo que permite la continuidad del ser, y en este caso el que confiere al sujeto poético el amor de todas las demás mujeres fatales mencionadas con anterioridad: el quiebre se realiza en los tercetos y la femme fatale comienza a aparecer a partir del «rojo beso ardiente» con la típica doble adjetivación modernista.

la enamorada esfinge quedará estupefacta,

apagaré la llama de la vestal intacta

iy la faunesa antigua me rugirá de amor! (Darío, 1996:123).

Es preciso retomar una idea de Octavio Paz sobre el erotismo dariano que llamó pasional en su artículo «El caracol y la sirena». Esta idea está en correspondencia con nuestra línea de lectura sobre la significación de lo femenino en Prosas profanas: «La mujer lo fascina. Tiene todas las formas naturales: colina, tigre, yedra, mar, paloma; está vestida de agua y de fuego y su desnudez misma es vestidura» (Paz, 2007: 33). Asimismo, Sucre considera que «el erotismo en Darío es una suerte de cosmología cuyo centro es el cuerpo de la mujer. Se trata, por tanto, de un verdadero panerotismo: el 
ánima del mundo es la atracción del deseo» (Sucre, 1975: 43). ${ }^{21}$ Como la mujer forma parte del universo sensual de Rubén Darío, lo mismo sucede con la palabra, ambas configuran su idea perfecta de poesía, el erotismo dariano es metapoético y se refiere siempre a la configuración de la poesía misma y en pleno Modernismo hispanoamericano, a la renovación de la poesía.

\section{OBRAS CITADAS}

Anderson Imbert, Enrique (1967), La originalidad de Rubén Darío, Buenos Aires, Centro Editor de América Latina.

Barría Navarro, José Nelson (1996), «Erotismo satánico y muerte en la obra de Rubén Darío: una revisión de sus influencias», Anales de la Literatura Hispanoamericana, 25, pp.125141.

Bataille, Georges (1981 [1954]), Breve historia del erotismo, Uruguay, Ediciones de la Bahía.

Bataille, Georges (2010 [1979]), El erotismo, Buenos Aires, Tusquets Editores.

Biblia de Jerusalén (1998), revisada y aumentada, Bilbao, Desclée de Brouwer.

Darío, Rubén (1939 [1888]), Azul..., en Obras escogidas, ed. Julio Saavedra y Erwin K. Mapes, Santiago, Imprenta Universo.

Darío Rubén (1996 [1896]), Prosas profanas y otros poemas, ed. Pedro Luis Barcia, Buenos Aires, Embajada de Nicaragua.

Giordano, Jaime (1979), «Rubén Darío a la luz del simbolismo», en José Olivio Jiménez (ed.), El simbolismo, Madrid, Taurus.

Gullón, Ricardo (1967), «Rubén Darío y el erotismo», Los papeles de Son Armandans, vol. XLVI, pp. 143-158.

Kristeva, Julia (1987 [1983]), Historias de amor, México, Siglo XXI editores.

Lafitte-Houssat, Jacques (1996), «El "arte de amar" de André Le Chapelain», «El código de amor», Trovadores y cortes de amor, Buenos Aires, Eudeba.

Litvak, Lily (1979), Erotismo fin de siglo, Barcelona, Antonio Bosch editor.

Ortega, Julio (2003), Rubén Darío, Barcelona, Ediciones Omega.

Patiño Káram, Juan Pablo (2005), «El erotismo en los cuentos de Azul... de Rubén Darío como propuesta vital», Espéculo. Revista de estudios literarios, 31. <http://webs.ucm.es/info/especulo/numero31/azulrd.html>.

Paz, Octavio (1991 [1982]), «Concilio de luceros», Sor Juana Inés de la Cruz o Las Trampas de la Fe, Buenos Aires, Fondo de Cultura Económica, pp. 260-282.

Paz, Octavio (1993), La llama doble, Barcelona, Seix Barral.

Paz, Octavio (2007 [1965]), «El caracol y la sirena», Antología de Rubén Darío, Madrid, Espasa Calpe.

Rama, Ángel (1985), «Prólogo», Poesía de Rubén Darío, Caracas, Biblioteca Ayacucho.

Salinas, Pedro (1978 [1948]), La poesía de Rubén Dario, Buenos Aires, Losada.

Sucre, Guillermo (1975), La máscara, la transparencia, Caracas, Monte Ávila Editores.

Verlaine, Paul (2011 [1869]), Poemas saturnianos. Fiestas galantes, ed. bilingüe Antonio Martínez Sarrión, Madrid, Hiperión.

${ }^{21}$ Sucre también dice sobre el erotismo: «Aún creo que su rebelión adopta formas más radicales: su exaltación del placer y su visión erótica del mundo encierran, sin duda, una crítica a la ética social y también a la concepción judeo-cristiana del amor» (Sucre, 1975: 31). 